\title{
An Index System for Financial Safety of China
}

\author{
Xiaojunjia ${ }^{1,2}$, MenggangLi ${ }^{1,2}$ \\ ${ }^{1}$ China Center for Industrial Security Research, Beijing Jiaotong University (China) \\ ${ }^{2}$ Beijing Center for Industrial Security and Development Research (China) \\ 13810582343@163.com, morganli@,vip.sina.com
}

Received: December 2014

Accepted: April 2015

\section{Abstract:}

Purpose: This paper combines a synthetic index system by the variables and evaluates China's financial safety through the change of indexes in a comprehensive way. First of all, it builds the financial industry evaluation index system composed of 25indicators in terms of the operation of the financial industry and external economic environment and particularly takes into consideration factors which might trigger liquidity risks such as off-balance-sheet business, interbank business and shadow banking; then it selects 10 indicators to conduct empirical analysis and identifies the indicator weight through principal component analysis; finally it combines the financial safety indexes through the linear weighted comprehensive evaluation model.

Design/methodology/approach: Synthesis of indexes is made by constructing a proper comprehensive evaluation mathematical model, integrating a number of evaluation indexes into one comprehensive evaluation index and then obtaining corresponding comprehensive evaluation results. In this paper, it selects 10 indexes to conduct empirical analysis and identifies the index weight through principal component analysis; finally it combines the financial safety indexes through the linear weighted comprehensive evaluation model. Principal component analysis (PCA) is a statistical procedure that uses an orthogonal transformation to convert a set of observations of possibly correlated variables into a set of values of linearly uncorrelated 
variables called principal components. PCA was invented in 1901 and was later independently developed (and named) by Harold Hotelling in the 1930s.

Findings: From 2003 to 2013 China’s financial safety indexes fluctuated. From 2003 to 2007 indexes rose, which indicates China's financial safety status gradually improved; from 2007 to 2009 indexes declined, which indicates due to the impact of subprime crisis, China's financial safety status took a turn for the worse; from 2009 to 2012 indexes rose, which indicates the external environment improved so did China's financial safety status; from 2012 to 2013 indexes declined because due to the rapid development of banks' financial products and trust products, banks' off-balance-sheet assets and liquidity risks increased. The changes of financial safety indexes are generally identical with those of China's financial safety status.

Research limitations/implications: In the empirical analysis part, this article tries to selective 24 indicators synthetic index of China's financial security, but due to some of the indicators data acquisition is relatively difficult, can only Selective 10 of 25 indicators and gather the annual data of 10 indicators from 2003 to 2013 to synthetic index. The information of eliminated indicators cannot be reflected in the index. Index change also does not reflect of the risk from these indicators. In order to make up for the above limitations, this paper is mainly to introduce and analysis our latest financial institutions business trends associated with these eliminated indicators to get the conclusions more reliable.

Originality/value: The aim of this research is to estimate financial safety of China with the application of the index of financial safety of a country using the annual data of 2003-2013. Through synthetic index of financial security measure the risks of China's financial system, provide the basis for the government macro financial policy. The Originality of the paper is mainly manifested in incorporating factors which have made important impacts on China's financial safety in recent years, but have not been taken into consideration in the existing studies into the newly constructed financial safety index system. For example, some factors that cannot be controlled easily might have huge hidden risk hazards. To be more specific, factors such as off-balance-sheet business, interbank business and shadow banking might trigger liquidity risks. In this way, the research results will be more practical.

Keywords: financial safety indexes, financial safety evaluation, principal component analysis 


\section{Introduction}

Financial safety is key to a country's economic safety because once financial crisis breaks out, it will be transmitted to the real economy and further threaten the national economic security. Since the 1990s financial crisis has broken out in Mexico, Asia, Russia, Brazil and America, doing great damage to the world economy and social development. How to accurately measure and evaluate a country's financial safety in a comprehensive way or accurately conduct risk warning in order to prevent financial crisis has become the focus and most difficult part of world financial research. Particularly in 2007 subprime crisis broke out in America and then quickly spread to the whole world. Original evaluation and early-warning methods focusing on banking crisis and currency crisis were challenged and study on financial risks began to pay more attention to relevance and infectiousness inside the financial system and system risks. For China, on the one hand, systematic risks which might be triggered by internal factors such as China's shadow banking system including trust companies and financial products, local government debts and real estate bubbles have constantly accumulated; on the other hand, with the constant improvement of RMB exchange rate formulation mechanism and implementation of financial reform measures such as accelerating market-oriented reform of interest rate, the financial industry has been increasingly opened up and the financial system has faced more and more risks of external impact. As a result, it is of great practical significance to select proper methods to measure financial safety and conduct scientific and comprehensive evaluation so as to prevent the outbreak of systematic crisis in time.

The remainder of the paper is divided into four sections. A review of the theoretical and empirical literature is provided in Section 2. Section 3 elaborates on the construction of the financial safety index system and the establishment of the evaluation model. Section 4 focuses on financial safety index synthesis and empirical analysis. The last section is devoted to conclusions and policy proposals.

\section{Literature Review}

There are three main methods used in the financial crisis early warning and comprehensive evaluation literature. The first one is early-warning models of financial crises, the second is a model to measure the contagious effects of financial risks among different financial areas, and the third is a synthetic index combined by the variables capturing all the key features of financial risks.

There are a number of studies of early-warning models of financial crises, such as STV crosscountry model (Sachs, Tornell \& Velasco, 1996), KLR signal analysis (Kaminsky, Lizondo \& Reinhart, 1998), FR probit/logit model (Frankel \& Andrew, 1997). 
After the U.S. subprime mortgage crisis in 2007, systemic risk measure model of contagious effects of financial risks is widely used in the empirical studies, such as GARCH Model (Tim Bollerslev, 1986), the network approach, which tracks the reverberation of a credit event or liquidity squeeze throughout the financial system (IMF, 2009), CoVaR measure (Adrian \& Bmnnermeier, 2008).

A synthetic index combined by the variables is an important tool to be applied to predict the likelihood of financial crises. Using statistical and econometric techniques, the variables are combined into a single index capturing all the key features of financial risks.

Compared with the former two methods, a synthetic index has the following advantages, such as simple, clear, operational flexibility, maintaining the continuity of the sequence, etc.

Financial stress index measure is the application of synthetic index method. Illingn and Liu (2003) first proposed the concept of financial stress and develop an index of financial stress called the financial stress index (FSI) for the Canadian financial system. Das, Iossifov, Podpiera and Rozhkovl (2005) develop multi-country indixes of financial system stress called the financial stress index and quality of financial policies called the index of quality of financial policies (IQFP) and use them in regression analysis of the determinants of financial stress. Moriyama (2010) develop the financial stress index of emerging market (EM) economies in the middle east and north Africa (MENA) to estimate spillover of the global crisis to MENA EM countries. Hakkio and Keeton (2009) combined 11 variables that capture the key characteristics of financial stress into a new index called the Kansas city financial stress index using principal component analysis. They suggest that policymakers will benefit from having a single comprehensive index to determine when financial stress is high enough to necessitate intervention and when the stress level has declined enough to warrant the unwinding of the special lending programs. Balakrishnan, Danninger, Elekdag and Tytell (2009) studies how financial stress, defined as periods of impaired financial intermediation, is transmitted from advanced to emerging economies using a new FSI for emerging economies. Cardarelli, Elekdag and Subir (2009) identifies episodes of financial turmoil using the FSI, and proposes an analytical framework to assess the impact of financial stress in particular banking distress on the real economy.

The synthetic index has been applied to predict the likelihood of financial crises in other empirical studies. Matkovskyy $(2012,2013)$ proposes an approach to explore the strength of the financial system of South Africa and Turkey respectively against the possibility of financial perturbations appearing based on the construction of the index of financial safety (IFS) of a country. It is shown that the IFS could capture the disturbances in the financial system. Zhang (2012) designs and builds systemic financial risk stress indicators to assess the systemic financial risk on the basis of systemic financial risk studies, and carries out empirical research on Shanghai's financial system. Dexu and Feng (2011) develop a comprehensive financial 
safety Index to measure the condition of China's current financial stability using the method of Principal Component Analysis. Hongbing and Jinmin (2014) constructs an aggregate financial stability index (AFSI) for China's financial system using the quarterly data of 2000Q1-2012Q3, and the AFSI is used to measure and predict the level of China's financial stability.

The aim of this research is to estimate financial safety of China with the application of the index of financial safety of a country using the annual data of 2003-2013. Its innovation is mainly manifested in incorporating factors which have made important impacts on China's financial safety in recent years, but have not been taken into consideration in the existing studies into the newly constructed financial safety index system. For example, some factors that cannot be controlled easily might have huge hidden risk hazards. To be more specific, factors such as off-balance-sheet business, interbank business and shadow banking might trigger liquidity risks. In this way, the research results will be more practical.

\section{Financial Safety Index Construction and Evaluation Model Establishment}

\subsection{Construction of the Financial Safety Evaluation Index System}

Financial safety evaluation is to conduct quantitative analysis on the safety of the financial industry based on the current development status of the financial industry in order to objectively and accurately grasp the safety status of the financial industry. The financial safety evaluation index system is constructed based on the characteristics of the financial industry and existing domestic and foreign research.

\subsubsection{Principles of Constructing the Financial Safety Index System}

System principle: There are a lot of factors that might affect financial safety. On the one hand, we should focus on those factors inside the financial industry; on the other hand, we should also examine the external environment of the financial industry including and domestic and foreign factors.

Scientific principle: For indexes reflecting the financial operation and its robustness, use international and national official regulatory standards for reference, for example, Basel Agreement III and relevant regulations and indexes used by China Banking Regulatory Commission to monitor the risks of banking institutions.

Real and comprehensive principle: In order to reflect the safety status of China's financial industry in a real and comprehensive way, in addition to some indexes applicable to all official regulation, we have selected some other indexes which are not included in the official 
regulation range, but have great impacts on the safety of the financial industry, for example, indexes related to off-balance-sheet business, interbank business and shadow banking business which have achieved a rapid growth in recent years.

Indexes should meet the requirements of quantitative analysis: Designed indexes should meet the requirements of quantitative analysis and meet the needs of finally calculating financial safety indexes.

\subsubsection{Financial Safety and its Main Indicators for China}

Different from real economy, products produced and operated in the financial industry are currency and negotiable securities, which characterized by high mobility and instability are more sensitive to domestic and foreign economic and policy fluctuation and more susceptible to impacts and risk factors. As a result, in constructing the first level indexes, the external economic environment of the financial industry and the operation of the financial industry should be taken into consideration.

External economic environment safety of the financial industry and its indicators:

Economic environment includes domestic and international environment while domestic environment encompasses macroeconomic operation and financial and policy environment.

Therefore, the following four indicators will be used to identify the states of macroeconomic operation: GDP growth rate, inflation rate, total fixed asset investment growth rate nationwide and registered urban unemployment rate.

Two indicators may therefore be useful in the financial and policy environment analysis: M2 year-on-year growth rate and ratio of off-balance-sheet assets in social financing structure.

Six indicators may therefore be useful in the international environment analysis:

- ratio of dependence on foreign trade (ratio of dependence on foreign trade= total volume of import and export of goods /GDP),

- debt service ratio (repayment of debt principal and interest / current year's trade and non trade foreign exchange revenue (BOP)), external debt ratio (outstanding external debt / GDP at current prices), foreign debt ratios (outstanding external debt / current year's trade and non trade foreign exchange revenue (BOP)), scale of capital inflow and outflow/currency reserves (refers to the capital and financial account balance in the balance of international payments and that in the financial) and monthly mean standard deviation of real effective exchange rate (refers to the weighted average of bilateral 
nominal exchange rate between the currency of one country and the currency of all trade partner countries).

Operation of the financial industry safety and its indicators:

Since the financial industry is characterized by high risks, high liquidity, unstability and high speculativeness, the financial industry operation indicators can be divided into operation status indicators and robustness indicators.

Seven indicators may be useful in the operation status analysis: total assets growth rate of banking institutions, credit balance/GDP, standard deviation of monthly interest rate in the inter-bank market, total assets growth rate of the insurance industry, total compensation growth rate of the insurance industry, stock market capitalization/GDP and Shanghai (Shenzhen) average price to earnings ratio.

Six indicators may be useful in the robustness status analysis: non-performing loan ratio of commercial banks, the proportion of commercial banks whose capital adequacy rate reaches $8 \%$, NPL provisioning coverage ratio of commercial banks, the proportion of inter-bank assets to total assets in the banking industry, average return rate of use of exchange insurance funds and monthly standard deviation Shanghai (Shenzhen) stock market price index.

\subsection{Synthesis of Financial Safety Indexes through the Linear Weighted Comprehensive Evaluation Model}

Synthesis of indexes is made by constructing a proper comprehensive evaluation mathematical model, integrating a number of evaluation indexes into one comprehensive evaluation index and then obtaining corresponding comprehensive evaluation results. In this paper, we choose to synthesize financial safety indexes through the linear weighted comprehensive evaluation model. the procedures for model construction are as follows:

\subsubsection{Samples Expressed in the Vector Form}

Suppose the evaluation index set has $\mathrm{n}$ evaluation indexes (generally all these $\mathrm{n}$ indexes are not independent, but related to each other) and $m$ samples. These $m$ samples of $n$ evaluation indexes can be expressed in the following vector form:

$$
\mathrm{X}_{(\mathrm{i})}=\left(\mathrm{x}_{\mathrm{i1}}, \mathrm{x}_{\mathrm{i} 2} \ldots \mathrm{x}_{\mathrm{im}}\right)^{\top} \text { and }(\mathrm{i}=1,2, \ldots, \mathrm{n})
$$

Select proper methods to weight $\mathrm{n}$ indexes and the weight vector can be expressed as:

$$
W=\left(w_{1}, w_{2}, \ldots, w_{n}\right)^{\top}
$$




\subsubsection{Comprehensive Evaluation Model}

Process primary data with various normalization methods and then construct the linear weighted comprehensive evaluation model with the processed data:

$$
\text { Index }=\mathrm{y}_{1} \mathrm{w}_{1}+\mathrm{y}_{2} \mathrm{w}_{2}+\ldots \mathrm{y}_{\mathrm{n}} \mathrm{w}_{\mathrm{n}}
$$

In the above formula, Index refers to the comprehensive evaluation value (numerical value); $w$ is the weight; $\mathrm{y}$ is the standardized index values obtained by processing primary data with standardized methods.

Various weighting techniques are considered, including: principal component analysis (or factor analysis), analytic hierarchy process (AHP), variance-equal weights, etc.

Principal component analysis (PCA) is a statistical procedure that uses an orthogonal transformation to convert a set of observations of possibly correlated variables into a set of values of linearly uncorrelated variables called principal components. PCA was invented in 1901 and was later independently developed (and named) by Harold Hotelling (1933) in the 1930s. The results of a PCA are usually discussed in terms of component scores, sometimes called factor scores (the transformed variable values corresponding to a particular data point) and loadings (the weight by which each standardized original variable should be multiplied to get the component score). Often, its operation can be thought of as revealing the internal structure of the data in a way that best explains the variance in the data and also can avoid the subjective interference in the evaluation process.

Therefore, in this paper, the factors extracted from the large data set considered are obtained using principal components analysis.

\section{Financial Safety Index Synthesis and Empirical Analysis}

\subsection{Data Selection and Processing}

In this paper there are two procedures for processing primary data: positive processing and normalization processing.

\subsubsection{Positive Processing of Data}

Financial safety evaluation indexes used in this paper can be divided into positive and negative indexes. Positive indexes refer to indexes that are safer when their numerical values are bigger, for example, assets growth rate and return rate while negative indexes refer to indexes that are safer when their numerical values are smaller, for example, ratio of non-performing 
loans and capital adequacy ratio. There are two kinds of negative indexes: those expressed in the form of percentage and those expressed in the form of numerical value(standard deviation). Indexes in percentage are positively processed with the formula: $X^{*}=100 \%-X$; standard deviation indexes are positively processed with the formula: $X^{*}=1 / X$, after the data are positively processed, conduct normalization processing to all indexes.

\subsubsection{Normalization Processing of Data}

In this paper we conduct standardized processing to data with Z-score (zero-mean normalization) method and the calculation formula: $X^{*}=\frac{(x-\mu)}{\sigma}$, in which $\mu$ refers to the mean value of all sample data and $\sigma$ refers to the standard deviation of all sample data.

\subsection{Principal Component Analysis}

We have only gathered the annual data of some micro financial indexes from 2003 to 2013, namely, altogether 11 observed values. Given the degree of freedom of variable data, we can at most select 10 indexes. In this paper we select the following 10 variables (as shown in Table 1) from the constructed financial safety indicators and conduct principal component analysis with Stata 11 software.

\begin{tabular}{|c|c|c|c|}
\hline $\begin{array}{c}\text { Evaluation } \\
\text { target }\end{array}$ & \multicolumn{2}{|c|}{ Classification standard } & Specific indexes \\
\hline \multirow{5}{*}{$\begin{array}{l}\text { Financial } \\
\text { Safety } \\
\text { Index } \\
\text { Calculation } \\
\text { And } \\
\text { Selection } \\
\text { Index }\end{array}$} & \multirow{3}{*}{$\begin{array}{l}\text { Economic } \\
\text { Environment }\end{array}$} & \multirow{2}{*}{$\begin{array}{l}\text { Domestic } \\
\text { Environment }\end{array}$} & $\begin{array}{l}\text { GDP growth rate } \\
\text { inflation rate }\end{array}$ \\
\hline & & & $\begin{array}{l}\text { M2 year-on-year growth rate } \\
\text { ratio of off-balance-sheet assets in social financing structure }\end{array}$ \\
\hline & & $\begin{array}{l}\text { International } \\
\text { Environment }\end{array}$ & $\begin{array}{l}\text { scale of capital inflow and outflow/currency reserve } \\
\text { monthly mean standard deviation of real effective exchange rate }\end{array}$ \\
\hline & \multirow[b]{2}{*}{$\begin{array}{l}\text { Financial } \\
\text { Industry } \\
\text { Operation }\end{array}$} & Operation Status & $\begin{array}{l}\text { Bank: standard deviation of monthly interest rate in the inter- } \\
\text { bank market }\end{array}$ \\
\hline & & $\begin{array}{l}\text { Evaluation of } \\
\text { Robustness }\end{array}$ & $\begin{array}{l}\text { Bank: non-performing loan ratio of commercial banks } \\
\text { NPL provisioning coverage ratio of commercial banks } \\
\text { Financial market: Shanghai (Shenzhen) stock market price } \\
\text { index }\end{array}$ \\
\hline
\end{tabular}

Table 1. Variables Included in the Financial Safety Index

Through the principal component analysis we can obtain principal component eigenvalues, Dvalue of eigenvalues, variance contribution rate and cumulative variance contribution rate shown in Table 2. It can be seen from Table 2 that all the first four eigenvalues are greater than 1 and the cumulative variance contribution rate reaches $84.64 \%$, which indicates the first four principal components generally include the information of all indexes. It can be found explicitly from the principal component analysis scree plot in Figure 1 that from the first to the fourth principal components, the change of eigenvalues is quite significant and then from the 
fifth one on, the change of eigenvalues tends to become steady. As a result, in this paper we select the first four principal components to replace the previous 10 indexes.

In addition, through the principal component analysis we can obtain the factor loading matrix in which the coefficient of the factor expression of all original variables indicates the degree of effect of the extracted common factors on original variables. The greater the absolute value of the factor loading is, the higher the correlation between common factors and original variables is and the more the obtained common factors can comprehensively reflect the information of original variables. It can be seen from the factor loading matrix in Table 3 that in principal component 1 the absolute values of load coefficients of non-performing loan ratio of commercial banks, ratio of off-balance-sheet assets in social financing structure, NPL provisioning coverage ratio of commercial banks, scale of capital inflow and outflow/currency reserves and monthly mean standard deviation of 7-day interbank offered rate are quite great, which indicates principal component 1 can comprehensively reflect these 5 indexes; in principal component 2 the absolute values of load coefficients of GDP growth rate and CPI are quite great, which indicates principal component 2 can comprehensively reflect these 2 indexes; in principal component 3 the absolute values of load coefficients of $M_{2}$ growth rate and standard deviation of the month-end indexes of the Shanghai composite index are quite great, which indicates principal component 3 can comprehensively reflect these 2 indexes; in principal component 4 the absolute value of load coefficient of the mean standard deviation of real effective exchange rate is quite great, which indicates principal component 4 mainly represents this index.

\begin{tabular}{|c|r|r|r|r|}
\hline Component & Eigenvalue & Difference & Proportion & \multicolumn{1}{c|}{ Cumulative } \\
\hline Comp1 & 4.0634 & 2.3143 & 0.4063 & 0.4063 \\
\hline Comp2 & 1.7491 & 0.1773 & 0.1749 & 0.5812 \\
\hline Comp3 & 1.5717 & 0.4915 & 0.1572 & 0.7384 \\
\hline Comp4 & 1.0802 & 0.3985 & 0.1080 & 0.8464 \\
\hline Comp5 & 0.6817 & 0.1443 & 0.0682 & 0.9146 \\
\hline Comp6 & 0.5374 & 0.3917 & 0.0537 & 0.9684 \\
\hline Comp7 & 0.1457 & 0.0227 & 0.0146 & 0.9829 \\
\hline Comp8 & 0.1230 & 0.0778 & 0.0123 & 0.9952 \\
\hline Comp9 & 0.0452 & 0.0426 & 0.0045 & 0.9997 \\
\hline Comp10 & 0.0026 & 0.0000 & 0.0003 & 1.0000 \\
\hline
\end{tabular}

Table 2. Table of Principal Component Eigenvalues and Contribution Rate 


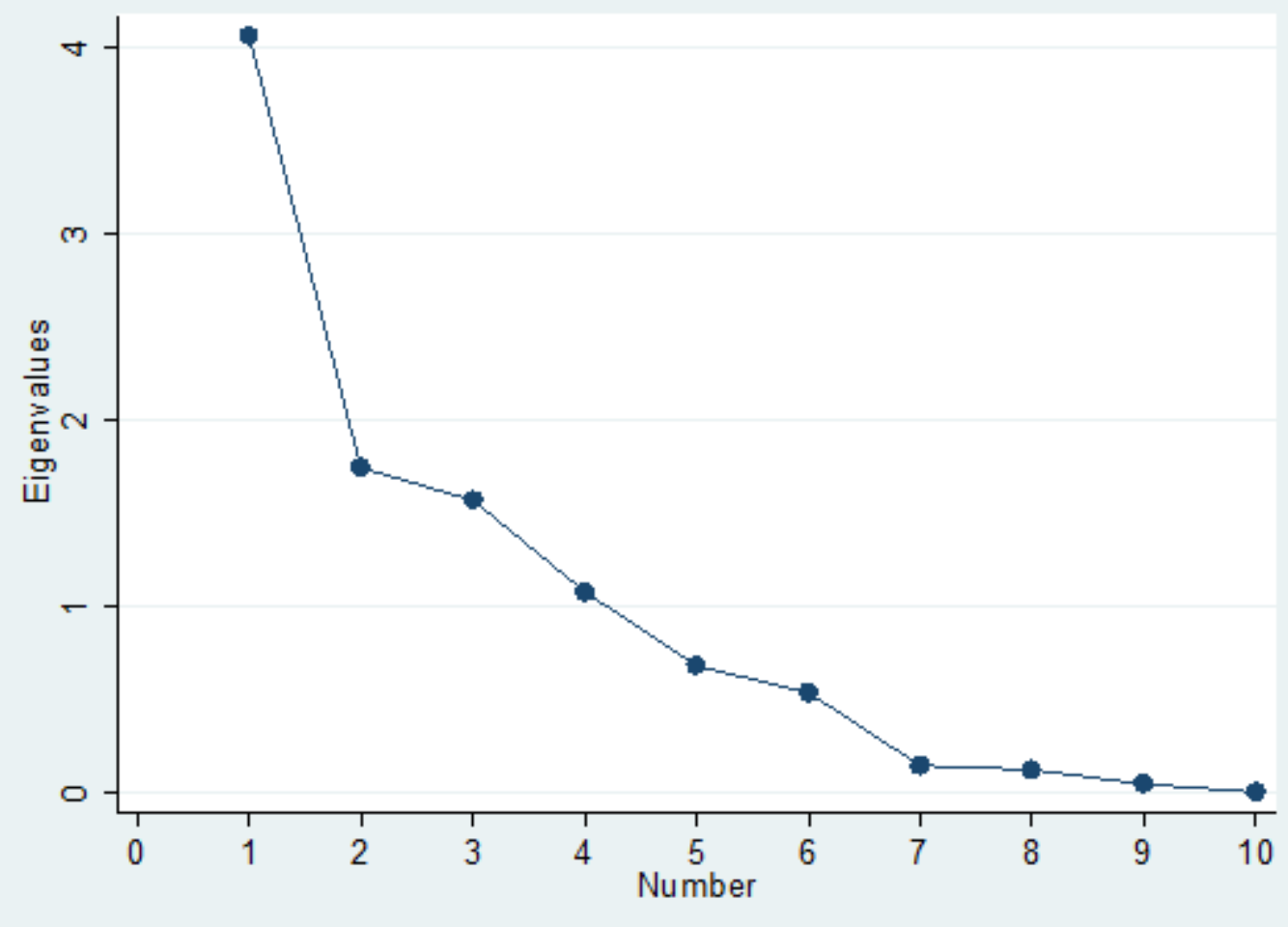

Figure 1. Principal Component Analysis Scree Plot

\begin{tabular}{|l|r|r|r|r|}
\hline \multicolumn{1}{|c|}{ Index } & \multicolumn{1}{c|}{ Comp1 } & \multicolumn{1}{c|}{ Comp2 } & \multicolumn{1}{c|}{ Comp3 } & \multicolumn{1}{c|}{ Comp4 } \\
\hline GDP growth rate & -0.3526 & 0.6347 & -0.6109 & 0.1095 \\
\hline CPI & -0.3771 & -0.6311 & -0.1212 & 0.6188 \\
\hline M2 growth rate & 0.3259 & 0.6303 & 0.6359 & -0.0740 \\
\hline Scale of capital inflow and outflow/currency reserves & 0.7239 & 0.0490 & -0.3333 & 0.2381 \\
\hline Non-performing loan ratio of commercial banks & 0.8889 & -0.2503 & -0.1954 & -0.1128 \\
\hline $\begin{array}{l}\text { Ratio of off-balance-sheet assets in social financing } \\
\text { structure }\end{array}$ & -0.8569 & -0.0559 & -0.2249 & -0.1020 \\
\hline NPL provisioning coverage ratio of commercial banks & 0.8635 & -0.3538 & 0.3143 & -0.0126 \\
\hline $\begin{array}{l}\text { Monthly mean standard deviation of real effective } \\
\text { exchange rate }\end{array}$ & 0.3094 & 0.5739 & 0.1010 & 0.6670 \\
\hline $\begin{array}{l}\text { Monthly mean standard deviation of 7-day interbank } \\
\text { offered rate }\end{array}$ & -0.7227 & 0.0509 & 0.3133 & -0.1758 \\
\hline $\begin{array}{l}\text { Standard deviation of the month-end indexes of the } \\
\text { Shanghai composite index }\end{array}$ & -0.5279 & -0.1596 & 0.6103 & 0.3521 \\
\hline
\end{tabular}

Table 3. First Four Principal Component loadings(unrotated) Matrix

After selecting principal components, principal components become the new indexes replacing original ones. Then we calculate the scores of four principal components in each year and based on the factor score coefficient matrix (as shown in Table 4) and the calculation formula is as follows:

$$
\begin{gathered}
f_{1}=-0.1749 x_{1}-0.1871 x_{2}+0.1617 x_{3}+0.3591 x_{4}+0.4410 x_{5}-0.4251 x_{6}+0.4284 x_{7} \\
+0.1535 x_{8}-0.3585 x_{9}-0.2619 x_{10} \\
f_{2}=0.4799 x_{1}-0.4772 x_{2}+0.4766 x_{3}+0.0370 x_{4}-0.1892 x_{5}-0.0423 x_{6}-0.2675 x_{7} \\
+0.4339 x_{8}+0.0385 x_{9}-0.1207 x_{10}
\end{gathered}
$$




$$
\begin{gathered}
f_{3}=-0.4872 x_{1}-0.0967 x_{2}+0.5072 x_{3}-0.2659 x_{4}-0.1559 x_{5}-0.1794 x_{6}+0.2507 x_{7} \\
+0.0806 x_{8}+0.2499 x_{9}+0.4868 x_{10} \\
f_{4}=0.1053 x_{1}+0.5954 x_{2}-0.0712 x_{3}+0.2291 x_{4}-0.1086 x_{5}-0.0981 x_{6}-0.0121 x_{7} \\
+0.6418 x_{8}-0.1691 x_{9}+0.3388 x_{10}
\end{gathered}
$$

$\left(\mathrm{x}_{1} \ldots \mathrm{x}_{10}\right.$ represent the 10 indexes obtained through normalization processing respectively).

We calculate the scores of principal components from 2003 to 2013 and the calculation results are shown in Table 5. Figure 2 shows the change trend of the scores of the first four principal components from 2003 to 2013.

\begin{tabular}{|l|r|r|r|r|}
\hline \multicolumn{1}{|c|}{ Index } & \multicolumn{1}{c|}{ Comp1 } & \multicolumn{1}{c|}{ Comp2 } & \multicolumn{1}{c|}{ Comp3 } & \multicolumn{1}{c|}{ Comp4 } \\
\hline GDP growth rate & -0.1749 & 0.4799 & -0.4872 & 0.1053 \\
\hline CPI & -0.1871 & -0.4772 & -0.0967 & 0.5954 \\
\hline M2 growth rate & 0.1617 & 0.4766 & 0.5072 & -0.0712 \\
\hline Scale of capital inflow and outflow/currency reserves & 0.3591 & 0.0370 & -0.2659 & 0.2291 \\
\hline Non-performing loan ratio of commercial banks & 0.4410 & -0.1892 & -0.1559 & -0.1086 \\
\hline $\begin{array}{l}\text { Ratio of off-balance-sheet assets in social financing } \\
\text { structure }\end{array}$ & -0.4251 & -0.0423 & -0.1794 & -0.0981 \\
\hline NPL provisioning coverage ratio of commercial banks & 0.4284 & -0.2675 & 0.2507 & -0.0121 \\
\hline $\begin{array}{l}\text { Monthly mean standard deviation of real effective } \\
\text { exchange rate }\end{array}$ & 0.1535 & 0.4339 & 0.0806 & 0.6418 \\
\hline $\begin{array}{l}\text { Monthly mean standard deviation of 7-day interbank } \\
\text { offered rate }\end{array}$ & -0.3585 & 0.0385 & 0.2499 & -0.1691 \\
\hline $\begin{array}{l}\text { Standard deviation of the month-end indexes of the } \\
\text { Shanghai composite index }\end{array}$ & -0.2619 & -0.1207 & 0.4868 & 0.3388 \\
\hline
\end{tabular}

Table 4. First Four Principal Component eigenvectors

\begin{tabular}{|r|r|r|r|r|}
\hline year & Comp1 & Comp2 & Comp3 & \multicolumn{1}{|c|}{ Comp4 } \\
\hline 2003 & -3.0750 & -0.5590 & 0.7579 & 0.6770 \\
\hline 2004 & -2.8006 & 1.0653 & 1.4173 & -1.0961 \\
\hline 2005 & -2.2863 & -0.0588 & 0.4355 & 0.5800 \\
\hline 2006 & -0.4644 & 0.8278 & -1.4690 & 0.7926 \\
\hline 2007 & 0.4527 & 2.4275 & -1.5371 & 0.3901 \\
\hline 2008 & 0.8959 & 0.0497 & -0.9203 & -1.7852 \\
\hline 2009 & -0.6530 & -2.9397 & -1.7345 & 0.0376 \\
\hline 2010 & 1.4740 & -0.1132 & -0.4098 & 0.1123 \\
\hline 2011 & 1.7530 & 0.0341 & 0.6930 & -1.4101 \\
\hline 2012 & 2.6261 & 0.1502 & 1.1691 & 1.6841 \\
\hline 2013 & 2.0776 & -0.8837 & 1.5979 & 0.0178 \\
\hline
\end{tabular}

Table 5. First Four Principal Component Factor Score Table

Then with the calculated scores of the first 4 principal components and through the weighted average calculation, we obtain the comprehensive evaluation score of these 4 principal components in each year which is represented by $F$. The weight is the principal component variance contribution rate. Then the calculation formula is as follows:

$$
\mathrm{F}=\mathrm{W}_{1} \mathrm{f}_{1}+\mathrm{W}_{2} \mathrm{f}_{2}+\mathrm{W}_{3} \mathrm{f}_{3}+\mathrm{W}_{4} \mathrm{f}_{4}
$$

in which $w_{1}, w_{2}, w_{3}, w_{4}, f_{1}, f_{2}, f_{3}, f_{4}$ are the variance contribution rates of the first 4 principal components whileare the scores of first 4 principal components respectively. 
After the comprehensive evaluation score is calculated, based on the expression habit of indexes, we map the calculated $F$ value into the $\left[\begin{array}{ll}0 & 100\end{array}\right]$ interval and then obtain financial safety indexes. The conversion formula is as follows: index $=\frac{(\mathrm{F}-\mathrm{MinF})}{(\mathrm{MaxF}-\mathrm{MinF})}$, in which $\operatorname{MaxF}$ and MinF represent the maximum value and minimum value of the comprehensive evaluation score.

The calculated results of the comprehensive evaluation scores and financial safety indexes in each year are shown in Table 6.

\begin{tabular}{|r|r|r|}
\hline Year & Comprehensive score & Financial safety index \\
\hline 2003 & -1.1549 & 0.0000 \\
\hline 2004 & -0.8471 & 11.7737 \\
\hline 2005 & -0.8081 & 13.2668 \\
\hline 2006 & -0.1892 & 36.9450 \\
\hline 2007 & 0.4090 & 59.8323 \\
\hline 2008 & 0.0352 & 45.5321 \\
\hline 2009 & -1.0481 & 4.0856 \\
\hline 2010 & 0.5268 & 64.3391 \\
\hline 2011 & 0.6749 & 70.0038 \\
\hline 2012 & 1.4589 & 100.0000 \\
\hline 2013 & 0.9427 & 80.2492 \\
\hline
\end{tabular}

Table 6. Principal Component Analysis Comprehensive Score and Financial Safety Indexes

Figure 3 indicates the change trend of financial safety indexes from 2003 to 2013 which fluctuates and specifically can be divided into the following four stages: the indexes rising stage from 2003 to 2007; the indexes declining stage from 2007 to 2009; the indexes rising stage from 2009 to 2012; the indexes declining stage from 2012 to 2013. 


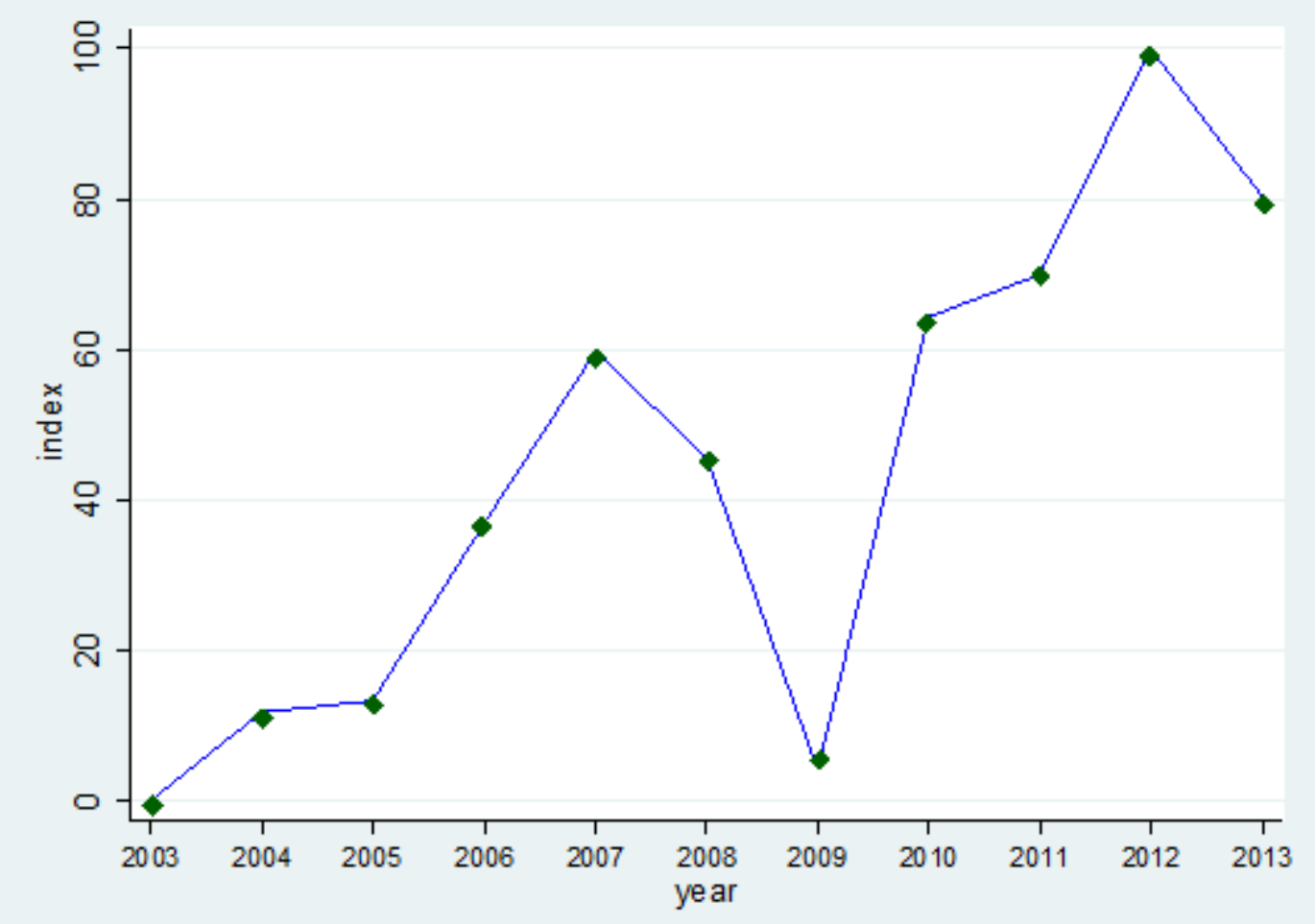

Figure 3. Financial Safety Index Change Trend (2003-2013)

As shown in Figure 3, in the first stage the indexes present a rising tendency, which indicates from 2003 to 2007 China's financial safety status gradually improved. Now we are going to explain it in terms of management and supervision of commercial banks. From the perspective of supervision, after in 2003 China Banking Regulatory Commission was established, there formed the new pattern of financial supervision, namely, "one bank and three commissions" which refer to the People's Bank of China, China Banking Regulatory Commission, China Securities Regulatory Commission and China Insurance Regulatory Commission and the management system of separate operation and separate supervision was further established. On December 27, 2003 China Banking Regulatory Commission issued Law of the PRC on Supervision over the Banking Industry to strengthen its supervision over commercial banks. Judging from the management of commercial banks, in October 2003 resolution of the Third Plenary Session of the Party's Sixteenth National Central Committee clearly stipulated selecting some qualified state-owned commercial banks to implement the joint-stock system reform. From 2005 to 2007 Bank of Communications H shares, China Construction Bank H shares, People's Bank of China $\mathrm{H}$ shares, People's Bank of China A shares, Industrial and Commercial Bank of China $\mathrm{A}$ and $\mathrm{H}$ shares, Bank of Communications $\mathrm{A}$ shares and China Construction Bank A shares were listed in Hong Kong or Shanghai successively. The listing of state-owned commercial banks accelerated the disposal of NPLs and capital adequacy. As a result, nonperforming loan ratio of commercial banks dropped significantly; NPL provisioning coverage ratio of commercial banks gradually increased; capital adequacy ratio reached the standard. 
In the second stage, the indexes plummet, which indicates during this period China's financial safety status took a turn for the worse and in 2009 it dropped to the bottom. It is mainly because in the second half of 2007 subprime crisis broke out in America and then quickly spread to the whole world in 2008. Due to the financial crisis, the world financial system lacked confidence and the financial market's fluctuation intensified. In 2008 the world economic growth rate dropped by $1.78 \%$ as compared with 2007 (see CBRC 2008 Annual Report). China's economy also withstood severe tests of the financial crisis in 2008 and 2009. First of all, it had a negative impact on China's foreign trade import and export. In 2008 the annual total import and export volume of goods was $\$ 2,561.6$ billion and month-on-month growth rate of import and export volume of goods dropped from $23.5 \%$ in 2007 to $17.8 \%$. In 2009 the annual total import and export volume of goods was $\$ 2,207.2$ billion, down $13.9 \%$ year on year: the export volume of goods was $\$ 1,201.7$ billion, down $16.0 \%$; the import volume of goods was $\$ 1,005.6$ billion, down $11.2 \%$. Gap between imports and exports (exports minus imports) was $\$ 196.1$ billion, decreasing by $\$ 102$ billion year on year (Statistical Communique of the People's Republic of China on the 2009 National Economic and Social Development). In addition, the financial crisis resulted in falling domestic demand. In 2009 CPI dropped by $0.7 \%$. Due to the decline of foreign trade and insufficient domestic demand, GDP growth rate dropped from $14.2 \%$ in 2007 to $9.6 \%$ in 2008 and then to $9.2 \%$ in 2009 . Judging from Shanghai Composite Index, Shenzhen Composite Index and fluctuation of real effective exchange rate, the fluctuation range climaxed in 2008 and then began to decline in 2009, which indicates due to the impact of the financial crisis, during this period China's exchange rate of imports and exports and stock market fluctuated significantly. In addition, in 2009 China implemented the loose monetary policy. At the end of 2009 M2 and M1 grew by $27.7 \%$ and 32.4\% respectively, both being the highest growth since 1996 and 1993 respectively. The annual new RMB loans reached RMB 9.59 trillion, increasing by RMB 4.69 trillion or $31.7 \%$ year on year, the highest since 1985. The credit support for economic development was quite great. The monetary aggregate grew rapidly; monetary liquidity continuously strengthened; financial risked increased.

In the third stage indexes present the rising tendency, which indicates from 2009 to 2012 China's financial safety status constantly improved. In 2009 the world economy gradually recovered. As a result, China's external environment also took a turn for the better and economy restored its balanced and rapid development. In 2010 GDP growth rate reached $10.4 \%$. During this period macro economy performed quite well while in terms of micro economy non-performing loan ratio of commercial banks continued to decrease and NPL provisioning coverage ratio of commercial banks continued to increase.

In the fourth stage compared with 2012 the indexes began to decline, which indicates in 2013 there emerged more financial insecurity factors. It is mainly manifested in two aspects. On the one hand, in May 2013 the liquidity in the interbank market tightened and the interbank offered rate constantly increased. Take the 7-day interbank offered rate as an example, its 
maximum in June reached $12.25 \%$ and the interest rate volatility increased. On the other hand, due to the rapid development of banks' financial products and trust products, offbalance-sheet assets and liquidity risks increased.

It can be seen from the above analysis that the changes of financial safety indexes are generally identical with those of China's financial safety status, which proves the financial safety indexes calculated in this paper can well reflect the actual situation of China's basic financial safety status. On the other hand, based on the changes of the calculated indexes, we can make targeted measures to deal with risks and guard against and defuse financial risks so as to provide empirical support for financial institutions' risk management and control and financial supervision departments' effective supervision.

\section{Conclusion and Policy Proposals}

\subsection{Conclusion}

Empirical results indicate: from 2003 to 2013 China's financial safety indexes fluctuated. From 2003 to 2007 indexes rose, which indicates China's financial safety status gradually improved; from 2007 to 2009 indexes declined, which indicates due to the impact of subprime crisis, China's financial safety status took a turn for the worse; from 2009 to 2012 indexes rose, which indicates the external environment improved so did China's financial safety status; from 2012 to 2013 indexes declined because due to the rapid development of banks' financial products and trust products, banks' off-balance-sheet assets and liquidity risks increased. The changes of financial safety indexes are generally identical with those of China's financial safety status.

\subsection{Policy Proposals}

Judging from the development trend of the global financial industry, comprehensive management is the general trend. If China intends to promote comprehensive management, it should further strengthen supervision and coordination in the current supervision system. What's more, specifically, we need to further strengthen the supervision of comprehensive management in the following aspects: 


\subsubsection{Make Laws, Rules and Regulations Related to Comprehensive Management of the Financial Industry as Soon as Possible}

At present in China comprehensive management has formed a certain scale and there has emerged a lot of new forms. Comprehensive management will result in more financial risk factors interweaving and interpenetrating. It will be hard for financial institutions lacking the ability to control risks to effectively guard against potential risks. Therefore, it is urgent that there must be laws to abide by and supervision should be executed according to the laws. In developed countries only after relevant laws, rules and regulations are made will the comprehensive management mode be implemented in the financial industry. However, in order to implement comprehensive management in the legal framework of separate operation at present in China, the Chinese government should make laws, rules and regulations related to comprehensive management of the financial industry as soon as possible.

\subsubsection{Strengthen the Systematicness and Sustainability of Financial Supervision and Constantly Improve Regulatory Means and Technologies}

Strengthen the supervision of off-balance-sheet business; constantly improve regulatory means and technologies; with consolidated supervision as the core, establish the comprehensive risk monitoring system covering financial institutions' on-balance-sheet and offbalance-sheet businesses; strengthen macro prudential regulation of systematic risks; in terms of capital, liquidity and risk management, make stricter requirements for large institutions of comprehensive management.

With the emerging of innovations of Internet finance, the People's Bank of China should also change its supervision mentality and way and constantly improve regulatory means and technologies.

On the one hand, regulatory departments should keep up with the pace of the Internet finance in regulatory means and technologies and supervise payment institutions and the Internet finance properly. Meanwhile it should spare some room and space from innovation and development. These are the challenges the regulatory authorities are facing and will face in the future. On the other hand, they should change the supervision way from "supervising institutions" to "supervising businesses". In the future payment institutions should be supervised according to unified business standards and regulations regardless of their asset size and market share. 


\subsubsection{Perfect the Financial Supervision and Coordination Mechanism and Strengthen the Financial Supervision and Management Ability}

Off-balance-sheet business, interbank business and shadow banking are the main factors that might trigger liquidity risks currently in China. In the future we should perfect financial supervision and coordination mechanism, enhance financial supervision ability and strengthen the cross-border supervision over off-balance-sheet business, interbank business and shadow banking to promote the standardization development of the emerging financial industry.

\section{References}

Adrian, T., \& Bmnnermeier, M.K. (2009). CoVaR. Paper Presented at the CEPR/ESI 13th Annual Conference on Financial Supervision in an Uncertain World on 25-26 September 2009 in Venice. Staff Report 348, Federal Reserve Bank of New York.

http://dx.doi.org/10.2139/ssrn.1269446

Balakrishnan, R., Danninger, S., Elekdag, S., \& Tytell, I. (2009). The Transmission of Financial Stress from Advanced to Emerging Economies. IMF Working Paper, No.133. Available online in: http://www.imf.org/external/pubs/ft/weo/2009/01/pdf/c4.pdf

Bollerslev, T. (1986). Generalized autoregressive conditional heteroskedasticity. Journal of Econometrics, 31, 307-327. North-Holland. http://dx.doi.org/10.1016/0304-4076(86)90063-1

Cardarelli, R., Elekdag, S., \& Subir, L. (2009). Financial Stress, Downturns, and Recoveries. IMF Working Paper, No. 100. Available online in: http://www.imf.org/external/pubs/ft/wp/2009/wp09100.pdf

Das, U.S., Iossifov, P., Podpiera, R., \& Rozhkovl, D. (2005). Quality of Financial Policies and Financial System Stress. IMF Working Paper, WP/05/173.

http://dx.doi.org/10.5089/9781451861921.001

Dexu, H., \& Feng, L. (2011). The Measurement and Analysis of Index of China's Financial Stability. Journal of Graduate School of Chinese Academy of Social Sciences, April, 16-25. Available online in: http://www.cnki.net/KCMS/detail/detail.aspx?QueryID

Frankel, J.A., \& Andrew, K.R. (1996). Currency Crashes in Emerging Markets: An Empirical Treatment. Journal of International Economics, 3, 351-366. http://dx.doi.org/10.1016/S00221996(96)01441-9

Hakkio, C.S., \& Keeton, W.R. (2009). Financial Stress: What Is It, How Can It Be Measured, and Why Does It Matter?. Economic Review, Federal Reserve Bank of Kansas City, Second Quarter, 5-50. Available online in: http://www.kansascityfed.org/PUBLICAT/ECONREV/pdf/09q2hakkio keeton.pdf 
Hongbing, G., \& Jinmin, D. (2014). The Construction and Application of China's Aggregate Financial Stability Index (AFSI) and Its Policy Implications. Journal of Finance and Economics, January, 59-65. Available online in: http://www.cnki.net/KCMS/detail/detail.aspx?QueryID

Hotelling, H. (1933). Analysis of a complex of statistical variables into principal components. Journal of Educational Psychology, 24, 417-441 and 498-520. http://dx.doi.org/10.1037/h0071325

Illing, M., \& Liu, Y. (2003). An Index of Financial Stress for Canada. Bank of Canada Working Paper. Available online in: https://ideas.repec.org/p/bca/bocawp/03-14.html

IMF (2009). Global Financial Stability Report: Responding to the Financial Crisis and Measuring Systemic Risk. Available online in: http://www.imf.org/external/pubs/ft/gfsr/2009/01/

Kaminsky, G.L., Lizondo, J.S., \& Reinhart, C.M. (1998). Leading Indicators of Currency Crises. Staff Papers of International Monetary Fund, 45(1), 1-48. http://dx.doi.org/10.2307/3867328

Matkovskyy, R. (2012). The Index of the Financial Safety (IFS) of South Africa and Bayesian Estimates for IFS Vector-Autoregressive Model. RePeC Working Paper. Available online in: http://mpra.ub.uni-muenchen.de/42173/1/MPRA_paper_42173.pdf

Matkovskyy, R. (2013). To the Problem of Financial Safety Estimation: The Index of Financial Safety of Turkey. MPRA_paper_47673. Available online in: http://mpra.ub.unimuenchen.de/47673/1/MPRA paper 47673.pdf

Moriyama, K. (2010). The Spillover Effects of the Global Crisis on Economic Activity in MENA Emerging Market Countries-An Analysis Using the Financial Stress Index. IMF Working Paper, No.8. http://dx.doi.org/10.5089/9781451961867.001

Sachs, J., Tornell, A., \& Velasco, A. (1996). Financial Crises in Emerging Markets: The Lessons from 1995. NBER Working Paper No. 5576. http://dx.doi.org/10.2307/2534648

Zhang, J. (2012). A Research of Systemic Financial Risk Assessment based on Financial Risk Stress Indicators. The Shanghai Financial, September, 53-57. Available online in: http://www.cnki.net/KCMS/detail/detail.aspx?QueryID

Journal of Industrial Engineering and Management, 2015 (www.jiem.org)

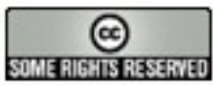

Article's contents are provided on a Attribution-Non Commercial 3.0 Creative commons license. Readers are allowed to copy, distribute and communicate article's contents, provided the author's and Journal of Industrial Engineering and Management's names are included. It must not be used for commercial purposes. To see the complete license contents, please visit http://creativecommons.org/licenses/by-nc/3.0/. 